\title{
The relationship between organisational culture and financial performance: some South African evidence
}

\author{
W.Z. van der Post, T.J. de Coning \& E.vdM. Smit \\ Graduate School of Business, University of Stellenbosch, P.O. Box 610, Bellville, 7535 Republic of South Africa
}

Received February 1998

\begin{abstract}
Although statistical evidence seems to be lacking, it is at present widely acknowledged that organisational culture has the potential of having a significant effect on organisational performance. An analysis of sustained superior financial performance of certain American organisations has attributed their success to the culture that each of them had developed. It has been proposed that these organisations are characterised by a strong set of core managerial values that define the ways in which they conduct business, how they treat employees, customers, suppliers and others. Culture is to the organisation what personality is to the individual. It is a hidden but unifying force that provides meaning and direction and has been defined as the prevailing background fabric of prescriptions and proscriptions for behaviour, the system of beliefs and values and the technology and task of the organisation together with the accepted approaches to these. Recent studies have indicated that corporate culture has an impact on a firm's long-term financial performance: that corporate culture will probably be an even more important factor in determining the success or failure of tirms in the next decade; that corporate cultures that inhibit long-term financial performance are not rare and that they develop easily, even in firms that are staffed by reasonable and intelligent people; and that corporate cultures, although difficult to change, can be made more performance enhancing. The purpose of this study, therefore, was to establish the statistical relationship between organisational culture and financial performance.
\end{abstract}

\section{Introduction}

The notion that workgroups in organisations develop their own behavioural norms and that the resulting mode of behaviour has an impact on an organisation's performance has been established long ago (Roethlisberger \& Dickson, 1975). It was, however, not until the late 1970 s that corporate or organisational culture became the subject of research projects (Davis, 1984; Deal \& Kennedy, 1982; Ouchi, 1981; Schein, 1992; Peters \& Waterman, 1982). Notwithstanding differences in research focus, terminology and methodology, the conclusions were very similar, that is all firms have corporate cultures, some have stronger cultures than others and these cultures can exert a powerful effect on individuals and on organisational performance (Kotter \& Heskett, 1992: 9).

The first systematic attempt to understand western work organisations in cultural terms occurred in the late 1920s with the well-known Hawthorne studies at the Western Electric Company. Specific findings from this research emphasised the importance of the culture of a work group, especially the norms regarding productivity and the attitude of workers towards management. The norms were found to have a greater impact on productivity than either technology or working conditions (Schuster, 1986: 25). Informal groups of workers were found to exert considerable control over the behaviour, including productivity, of individual group members (Roethlisberger \& Dickson, 1975: 561). The human relations movement sparked by the Hawthorne studies was directly relevant to today's efforts to understand and manage corporate culture (Kilman, Saxton \& Serpa, 1986: 92).

Early writers on organisational behaviour influenced many of the predominant ideas in current organisational culture literature (McIntyre-Ray, 1989: 20). McGregor, in
The human side of enterprise, stated that most managers make incorrect assumptions about those who work for them. He was among the first to suggest practical applications of the findings about corporate culture that came from the Hawthorne studies (McGregor, 1960). Argyris made a strong case for reducing the amount of organisational control. Many constraints placed by organisations on human beings are self-defeating to organisational goals of effectiveness and efficiency. He recommended that management develop a climate in which problems could be expressed openly and in which employee hostility could be understood and accepted (Argyris, 1964). Likert, in New patterns of management, concluded that a genuine interest and an unselfish concern on the part of the superior in the success and well-being of his subordinates have a marked effect on their performance. He emphasised the need for a corporate culture of cooperation and demonstrated that there was a significant correlation between employee attitudes and performance (Likert, 1961). Drucker in Management observed the reciprocal nature of the relationship between management and culture. He contended that management is, and should be, culture conditioned. Management and managers, in turn should shape culture (Drucker, 1973: xii).

The search for new ways to economic success also focused on the Japanese way of management. Ouchi in Theory $Z$ suggested that involved workers are the key to increased productivity (Ouchi, 1981). Pascale \& Athos assert that the prime determinant of success lies in the organisation's management. They call for greater management sophistication in respect of 'man-in-organisations' but also acknowledge that the effort to alter the managerial subculture will take a long time (Pascale \& Athos, 1981: 204205). Porter, Lawler \& Hackman stress that change and development activities in organisations do not take place in a 
vacuum. They are always embedded in an existing organisational climate or culture and this will have a vital impact on the degree of success of any efforts to alter or improve the organisation (Porter, Lawler \& Hackman, 1975: 489490). Peters and Waterman (1982) asserted that the key to productivity is the 'systems' within which employees work. The productivity-through-people concept is supported in a research study of 1300 major United States organisations. The conclusion of this report is that the dominant theme of American management practice will be the transformation of organisational culture towards more participative organisations that emphasise attention to empioyee needs as a major corporate strategy (Schuster, 1986: 159).

Notwithstanding the fact that statistical evidence seems to be lacking, it is currently acknowledged that corporate culture has the potential of having a significant effect on organisational performance. Superior financial performance of certain American organisations has been attributed to the culture that each of them had developed. It has been found that these organisations are characterised by a strong set of core managerial values that define the ways in which they conduct business. how they treat employees, customers, suppliers and others (Barney, 1986: 656).

Recent studies have indicated that corporate culture has an impact on a firm's long-term financial performance; that corporate culture will probably be an even more important factor in determining the success or failure of firms in the next decade; that corporate cultures that inhibit long-term financial performance are not rare and that they develop easily, even in firms that are staffed by reasonable and intelligent people; and that corporate cultures, although difficult to change, can be made more performance enhancing (Kotter \& Heskett, 1992: 11-12)

The purpose of this study, therefore, was to establish the statistical relationship between organisational culture and financial performance.

\section{Definition of organisational culture}

Culture is to the organisation what personality is to the individual. It is a hidden but unifying force that provides meaning and direction (Green, 1989: 72). This organisational personality is referred to as organisational culture that is a system of shared meaning, the prevailing background fabric of prescriptions and proscriptions for behaviour, the system of beliefs and values that ultimately shape employee behaviour.

Organisational culture has been defined in many ways by various authors. It has been described as the dominant values espoused by an organisation (Deal \& Kennedy, 1982), that it constitutes the philosophy that guides an organisation's policy towards employees and customers (Pascale \& Athos, 1981), that it is simply the way things are done in an organisation (Bower, 1966), as the basic assumptions and beliefs that are shared by members of an organisation (Schein, 1990), as the prevailing patterns of values, attitudes, beliefs, assumptions, expectations, activities. interactions, norms, and sentiments in an organisation (French \& Bell, 1984), as the sum of behaviour patterns that is built up over many years (White, 1991), as the set of values and assumptions that underlie the statement, 'This is how we do things around here' (Quinn, 1988), as the behaviour patterns or style of an organisation that new employees are automatically encouraged to follow (Kotter \& Heskett, 1992), as the underlying values, beliefis and principles that serve as a foundation for an organisation's management system as well as the set of management practices and behaviours (Denison, 1990).

Schein defined organisational culture as a pattern of basic assumptions invented, discovered or developed by a given group as it learns to cope with its problems of external adaptation and internal integration that has worked well enough to be considered valid and therefore is to be taught to new members as the correct way to think and feel in relation to those problems (Schein, 1990: 109-119).

Other authors define culture as the commonly held and relatively stable heliefs, attitudes and values that exist within an organisation (Williams, Dobson \& Walters. 1990), as patterns of belief's, symbols, rituals, myths and practices that have evolved over time in every organisation (Smircich, 1983), as what is typical of the organisation, the habits, the prevailing attitudes, the grown-up pattern of accepted and expected hehaviour (Drenan. 1992), as the patterned way of thinking. feeling and reacting that exists in an organisation or its subsectors (Tosi, Rizzo \& Carrol, 1990), as a social force that controls patterns of organisational behaviour by shaping members" cognitions and perceptions of meanings and realities, providing affective energy for mobilisation, and identifying who belongs and who does not (Ott, 1989).

All these definitions, however, have a central theme namely that organisational culture refers to a system of shared meaning, the prevailing background fabric of prescriptions and proscriptions for behaviour, the system of beliefs and values and the technology and task of the organisation together with the accepted approaches to these.

\section{Dimensions of organisationa! culture}

At the overt level, culture implies the existence of certain dimensions or characteristics that are closely associated and interdependent. Generally, however, research on organisational culture does not specify a set of uniform dimensions or characteristics. It is evident that researchers have applied a large number of dimensions of organisation culture that cannot be neatly categorised in terms of an overall organisational culture theory. From the literature, 114 dimensions of organisational culture have been identified.

Individually these dimensions were found not to be unique due to the fact that many of them. to some extent. overlapped. To develop an instrument by means of which organisational culture may be measured, it was necessary to distil from the 114 dimensions a set of unique dimensions.

To synthesise the dimensions identified, a panel consisting of human resource experts was requested to compare all the dimensions with each other and to group them into logical categories. The process followed entailed two steps.

In step one, all the dimensions with their definitions were recorded on cards. that is. one dimension per card. The 
panellists each received a set of these cards with the request to individually classify all the dimensions into categories on the basis of similarity. At the end of step one, the panel members had each created between 12 and 19 categories into which all the dimensions were classified.

In step two, the results of step one were fed back to the panel as a group with the request that they jointly discuss their respective categorisation of the dimensions with a view to reach consensus on those dimensions not already similarly categorised. This required a review of the categories already created as well as a reclassification of the dimensions. At the end of step two which required several sessions of discussion, 15 dimensions of culture emerged. They may be labelled and described as follows.

\section{Conflict resolution}

The degree to which the organisation is perceived to encourage employees to air conflicts and criticisms openly. Do subordinates perceive a willingness by superiors to hear different opinions? Is there an emphasis on getting problems out in the open as opposed to smoothing them over or ignoring them?

\section{Culture management}

The extent to which the organisation is actively and deliberately engaged in shaping the organisation's culture. Are there expressive events, ceremonies or rituals that are designed specifically to reinforce in a powerful and incontrovertible way the organisation's values and philosophies? Are there an understanding and belief in those core values and performance standards? Do employees understand and share a vision which unites the energies of the organisation's membership?

\section{Customer orientation}

The extent to which the organisation takes the views of customers seriously and actively responds to such views. Do employees perceive that emphasis is placed by everyone in the organisation on quality, service and reliability of products and services? Is there a willingness to listen to customers, to find out what they want and any ideas they may have for product improvement?

\section{Disposition towards change}

The degree to which employees are encouraged to be creative and innovative and to constantly search for better ways of getting the job done. Are employees in all parts of the organisation encouraged to experiment and to take practical risks? Are mistakes viewed as a natural occurrence in an innovative environment or are employees punished when their solutions to problems are imperfect? Is there a strong emphasis on experimentation or are employees expected to follow the book in dealing with business problems? Is there an emphasis on individual initiative?

\section{Employee participation}

The extent to which employees perceive themselves as participating in the decision-making process of the organisation. Are employees involved in making decisions which directly influence their work? Do they participate in setting individual and group goals? Do they have a say in broader policy matters?

\section{Goal clarity}

The degree to which the organisation creates clear objectives and performance expectations. Are employees clearly informed as to the plans and objectives of the organisation to understand their particular roles? Do they understand the mission, objectives and values of the organisation to the extent that they are prompted to work together as teams and to care about the quantity and quality of the organisation's outputs?

\section{Human resource orientation}

The extent to which the organisation is perceived as having a high regard for its human resources. Does the organisation view its employees as a valued resource and an important contributor to its success? Are rank and file employees seen as a key source of ideas for improvements in quality and productivity? Do employees perceive a commitment towards the development and training of the organisation's human resources? Do they experience systematic training and development interventions aimed at assisting them to develop to their full potential?

\section{Identification with the organisation}

The degree to which employees are encouraged to identify with the organisation. Does the organisation create opportunities for employees to socialise and to extend business friendships away from their work? Do employees experience an emotional involvement in their jobs and in the organisation? Do employees share a high degree of commitment to make the organisation's strategic vision a reality?

\section{Locus of authority}

The degree of responsibility, freedom and independence individual employees have. Is authority located mostly at the top of the organisation or is it in the hands of people actually doing the work? Is the management of the organisation centralised or decentralised? Are employees empowered to make appropriate decisions or do they have to refer these up the line? Do they have a perception of being able to manage and get on with the job or do they have to double-check all their decisions?

\section{Management style}

The degree to which managers provide clear communication, assistance and support to their subordinates. Do employees generally perceive higher levels of management to be helpful and supportive when needed or is it a case of 'sink or swim'? Do employees have confidence and trust in their supervisors? Is communication perceived to flow freely, accurately and undisturbed throughout the organisation upwards, downwards and laterally? Do employees feel that they have the information they need to do their jobs well? 


\section{Organisation focus}

The extent to which the organisation is perceived to be concentrating on those activities which form part of the fundamentals of the business. Does the organisation involve itself in activities which are peripheral to the fundamental business process or does it restrict itself to what it knows and does well?

\section{Organisation integration}

The degree to which various subunits within the organisation are actively encouraged to operate in a co-ordinated way by co-operating effectively towards the achievement of overall organisational objectives. Are employees encouraged to work in interdisciplinary teams across departmental boundaries to provide input into the design and delivery of the product or service to the customer? Is there a spirit among employees which causes them to share information and support each other across departmental or work group boundaries? Are employees encouraged to work with one another for the good of the organisation or is each unit or department working in isolation and often in conflict with one another?

\section{Performance orientation}

The extent to which emphasis is placed on individual accountability for clearly defined results and a high level of performance. Is it perceived as important to have clear goals and performance standards? Do employees perceive an emphasis on doing a good job? Do employees perceive individual and collective goals to be demanding and actively sought by supervisors? Do employees perceive a clear organisational norm to maintain progress and strive towards excellence?

\section{Reward orientation}

The degree to which reward allocations are based on employee performance in contrast to seniority or favouritism. Do employees perceive a linkage between reward and performance or is reward dependant on service, seniority, qualifications or other nonperformance related factors? Do employees perceive the organisation to place emphasis on positively reinforcing behaviour which supports the organisation's objectives as opposed to focusing on negatively punishing behaviour that does not support the organisation's objectives? Do employees perceive the organisation's reward system as reinforcing the notion that most employees are good performers or that most employees are not good performers?

\section{Task structure}

The degree to which rules and regulations and direct supervision is applied to manage employee behaviour. Do employees perceive the execution of their duties to be governed by rules, regulations, policies, procedures, working through channels or do they perceive a loose and informal atmosphere which allows them to be creative and innovative in pursuing the achievement of organisational objectives?
The constructs underlying each of the fifteen dimensions of culture have been summarised in Table 1. These constructs were utilised as the basis on which questionnaire items were produced for developing a questionnaire by means of which organisational culture may be measured.

\section{Development of an instrument to measure organi- sational culture}

The conventional method was followed in developing a questionnaire to measure the 15 constructs of organisational culture. A graphic Likert-type scale with seven points was used. An item analysis was carried out to select the best items and coefficient alpma was computed to determine the reliability of the instrument. Ninety-seven items, that is $57 \%$ of the original number of items were retained to measure the 15 dimensions. The reliability

\begin{tabular}{|c|c|}
\hline $\begin{array}{l}\text { Conflict } \\
\text { resolution }\end{array}$ & $\begin{array}{l}\text { The degree to which the organisation is perceived to } \\
\text { encourage employees to air conflicts and criticisms } \\
\text { openly }\end{array}$ \\
\hline $\begin{array}{l}\text { Culture } \\
\text { management }\end{array}$ & $\begin{array}{l}\text { The extent to which the organisation actively and } \\
\text { deliberately engages in shaping the organisation's } \\
\text { culture }\end{array}$ \\
\hline $\begin{array}{l}\text { Custome } \\
\text { orientation }\end{array}$ & $\begin{array}{l}\text { The extent to which the nrganisation takes the views } \\
\text { of customers seriously and actively responds to } \\
\text { such views }\end{array}$ \\
\hline $\begin{array}{l}\text { Disposition } \\
\text { towards change }\end{array}$ & $\begin{array}{l}\text { The degree to which employees are encouraged to } \\
\text { be creative and innovative and to constantly search } \\
\text { for better ways of getting the job done }\end{array}$ \\
\hline $\begin{array}{l}\text { Employee } \\
\text { participation }\end{array}$ & $\begin{array}{l}\text { The extent to which employees perceive themselves } \\
\text { as participating in the decision-making process of } \\
\text { the organisation }\end{array}$ \\
\hline Goal clarity & $\begin{array}{l}\text { The degree to which the organisation creates clear } \\
\text { objectives and performance expectations }\end{array}$ \\
\hline $\begin{array}{l}\text { Human resource } \\
\text { orientation }\end{array}$ & $\begin{array}{l}\text { The extent to which the organisation is perceived as } \\
\text { having a high regard for its human resources }\end{array}$ \\
\hline $\begin{array}{l}\text { Identification with the } \\
\text { organisation }\end{array}$ & $\begin{array}{l}\text { The degree to which employees are encouraged to } \\
\text { identify with the organisation }\end{array}$ \\
\hline Locus of authority & $\begin{array}{l}\text { The degree of authority, freedom and independence } \\
\text { that individual employees have in their jobs }\end{array}$ \\
\hline Management style & $\begin{array}{l}\text { The degree to which managers provide clear } \\
\text { communication, assistance and support to their } \\
\text { subordinates }\end{array}$ \\
\hline $\begin{array}{l}\text { Organisation } \\
\text { focus }\end{array}$ & $\begin{array}{l}\text { The extent to which the organisation is perceived to } \\
\text { be concentrating on those activities which form part } \\
\text { of the fundamentals of the business }\end{array}$ \\
\hline $\begin{array}{l}\text { Organisation } \\
\text { integration }\end{array}$ & $\begin{array}{l}\text { The degree to which various subunits within the } \\
\text { organisation are actively encouraged to operate in a } \\
\text { co-ordinated way by co-operating effectively } \\
\text { towards the achievement of overall organisational } \\
\text { objectives }\end{array}$ \\
\hline $\begin{array}{l}\text { Performance } \\
\text { orientation }\end{array}$ & $\begin{array}{l}\text { The extent to which emphasis is placed on } \\
\text { individual accountability for clearly defined results } \\
\text { and a high level of performance }\end{array}$ \\
\hline $\begin{array}{l}\text { Reward } \\
\text { orientation }\end{array}$ & $\begin{array}{l}\text { The degree to which reward allocations are based } \\
\text { on employee performance in contrast to seniority. } \\
\text { favouritism or any other nonperformance criterion }\end{array}$ \\
\hline $\begin{array}{l}\text { Task } \\
\text { structure }\end{array}$ & $\begin{array}{l}\text { The degree to which rules and regulations and } \\
\text { direct supervision are applied to manage employee } \\
\text { behaviour }\end{array}$ \\
\hline
\end{tabular}


coefficients for each of the culture dimensions varied between 0.788 and 0.932 .

Following the item analysis, the data relating to the retained 97 items were factor analysed. A principal factor analysis with an orthogonal varimax rotation yielded 15 factors with eigen values $>1.0$. High to moderate factor loadings on each of the factors were obtained - between 0.8408 and 0.3916 that suggests an acceptable level of construct validity.

\section{Measurement of organisational culture}

Sixty-three organisations of the 128 organisations invited to participate in the study accepted the invitation. Altogether 44 organisations declined to participate mainly for two reasons, namely that they had already allocated their research quota for the year or that their organisations were in the midst of cultural transformation programmes or had just come through them and that further cultural research would complicate their programmes. Twenty-one organisations failed to respond to the invitation.

In designing the sampling structure it proved too difficult to establish representative samples from nine companies due to their extremely diverse composition and organisation structure. These companies, therefore, were consciously eliminated from the study thus leaving a balance of 54 companies. A further five companies, finally, did not participate in the study because they were simply not able to provide the required data for drawing samples. In summary, therefore, a total of $49(38.3 \%)$ of the initial 128 companies invited, did in fact participate in the study.

In drawing random samples of respondents to the questionnaire from each of the participating organisations, geographical, functional and hierarchical considerations were taken into account.

Lists of employee names were obtained from each participating organisation. On a random basis every $n$th person was selected. Where this procedure yielded a small sample, that is fewer than 30 persons per category, $n$ was decreased until this minimum, where possible, was obtained. In anticipation of a low response rate to the completion of questionnaires, twice the required number of respondents, wherever possible, were randomly selected. A total number of 9471 persons were selected in respect of all the organisations.

Of all the questionnaires mailed, a total of 3676 (38.8\%) were returned. A follow-up letter reminding respondents about the questionnaire and requesting them to return it as soon as possible had very little effect.

Fifty-eight $(0.6 \%)$ questionnaires were not properly completed and as a consequence had to be discarded. The total number of questionnaires included in this study, therefore, numbered 3617 - an effective average response rate of $38.2 \%$. The lowest effective response rate was $33.1 \%$ and the highest $49.5 \%$.

Given the method of sampling, it was possible to obtain culture scores for the three organisational levels, management, supervisory and other, in respect of all 49 participating organisations. Of the 49 organisations 28 provided information in respect of functionally separate organisa- tions and of these organisations, 13 also differentiated information into geographical areas.

Measurements of organisational culture were obtained in respect of three broad categories namely all participating organisations, those organisations that reported functionally separate organisations and finally those organisations that reported geographically different locations. Five types of measurements were obtained namely, average culture scores in respect of each organisation, the variation in average culture score in respect of each organisation, the existence or otherwise of differences between average culture scores in respect of organisational level, functional unit and finally, geographical location.

\section{Organisational effectiveness: a complex matter}

The study of organisational behaviour is ultimately concerned with understanding the nature and determinants of organisational effectiveness. The literature on measures of organisational effectiveness reveals this to be a rather complex matter. Organisations have a wide variety of stakeholders and any particular measure of performance often tends to pit one against the other, for example shareholders prefer dividends but managers regard dividends as costs and usually prefer profits, growth and potential. This set of tradeoffs has led a number of authors to argue that effectiveness in organisations represents an inherent paradox (Denison, 1990: 35).

\section{A framework for understanding organisational effec- tiveness}

A number of conceptual frameworks for organisational effectiveness have been proposed. The natural systems model expands on the biological metaphor of an organism with an internally differentiated and integrated structure that is interdependent with its environment for information and energy. The implication is that organisations do not have goals and that they should be evaluated in terms of the equilibrium and elaboration of the system itself. This model emphasises criteria that will increase the long-term survival of the organisation (Robbins, 1990: 58).

The goal attainment model equates effectiveness with the attainment of specific organisational objectives. Goals may be a set of narrow economic objectives defined by owners or they may be the set of institutional goals defined by the organisation's constituents (Denison, 1990: 36).

The strategic-constituencies or resource dependence model proposes that an effective organisation is one that satisfies the demands of those constituencies in its environment from whom it requires support for its continued existence. It seeks to appease only those elements in its environment that can threaten its survival (Robbins, 1990: 62-63).

The decision process model has as a central theme that organisations are primarily information processing and decision-making entities and that the characteristics of this process will be foremost determinants and indicators of effectiveness (Denison, 1990: 37)

Finally there is the population ecology perspective that argues that the environment determines which types of organisations will survive and which will not and that the 
actions of individuals and organisations are relatively weak determinants of effectiveness. Certain species of organisations will grow to fill a particular niche and will decline accordingly when the demand for that particular type of organisation diminishes. This perspective assists to set a context within which the effectiveness of a particular firm might be analysed but does little to explain the fate of a particular organisation within a given niche (Denison, 1990: 37).

\section{Guidelines for assessing organisational effectiveness}

Cameron \& Whetten (1983: 262-274) come to the conclusion that there cannot be one universal model of organisational effectiveness and that it is more worthwhile to develop frameworks for assessing organisational effectiveness than to try to develop theories of effectiveness. They offer the following guidelines for assessing organisational effectiveness:

- Effectiveness should be defined and assessed from a particular point of view and that viewpoint should be made explicit.

- Organisational domains are circumscribed by the constituencies served, the technologies employed and the services or outputs produced. When effectiveness is analysed, it is, therefore, important that the domains being assessed are clearly specified.

- Judgements about effectiveness can be made at the individual, the subunit, the organisational, the industry or the societal level. The appropriateness of the level depends on the constituency used, the domain being focused on and the purpose of the evaluation.

- The purpose of judging effectiveness helps to determine the appropriate constituencies, domains and levels of analysis. A clear conception of purpose is therefore important.

- The selection of the time is important because longterm effectiveness may be incompatible with short-term effectiveness. Because judgements of effectiveness are always made within the context of a particular time frame, it is important that the latter be made explicit.

- The choice of data is between objective data (organisational records) or subjective, perceptual data (interviews or questionnaire responses). The selection of data by which to judge organisational effectiveness is important because an organisation may be judged effective on the basis of subjective perceptions while objective data may indicate that the organisation is ineffective.

- There are a variety of referents or standards against which organisational effectiveness can be judged. These are, for example comparative judgements, normative judgements, goal-centred judgements, improvement judgements and trait judgements. Because judgements of effectiveness may differ markedly depending on which referent is applied, it is important to be clear about the referent that serves as the basis for those judgements.
Practical applications of organisational effectiveness criteria by other researchers

Turning to the practical application of organisation effectiveness criteria it was found that Peters \& Waterman (1982: 22-23) applied six criteria in terms of which companies were assessed, that is, compound asset growth, compound equity growth, average ratio of market value to book value, average return on equity and average return on sales. In addition to these hard measures, they also applied a soft criterion based upon the opinions of experts on innovation and rapidity of response to changing markets. To qualify as a top performer, a company had to be in the top half of its industry in at least four of the six measures over a twentyyear period.

Ball \& Asbury (1989: 4) applied the all-in-return to shareholders, that is the share price of each company taken over a five-year period. In addition to this hard measure, they also added or deleted companies from their list based on discussions with financial analysts and commentators, the objective being to include companies from all significant sectors.

Kotter \& Heskett (1992: 19) applied three different criteria: the average yearly increase in net income; the average yearly return on investment; and the average yearly increase in stock price over a twelve-year period.

Nasser \& Vivier (1992: 19) point out that corporate performance depends on the researcher's particular point of view and that South African observers more often than not regard financial ratios as the single most important factor in judging corporate success. In their assessment of South African companies they relied not only on statistical parameters but also on a substantial amount of subjective information, for example, the prevalence of traditional approaches, attitudes, ideas, practices and behaviour.

\section{Motivation for using hard financial data as success criteria}

The fact that hard financial data have been be applied to differentiate between organisations in terms of their respective levels of effectiveness, should not be viewed as an attempt to negate other possible indicators of organisational effectiveness.

From a systems perspective wherein the organisation is viewed as a system, it can be argued that hard financial data perhaps offer a more appropriate basis on which organisational effectiveness can be measured. This argument is based on the premise that financial data form an integral part of various systems dimensions. First, from a structural perspective, financial considerations are evident in the nature of many entities that are incorporated in the system. Secondly, from a process perspective, the financial aspect both impacts on and is one of the manifestations of the dynamic relationship between entities in the system. Thirdly, from a function perspective, the financial aspect particularly in terms of financial performance, will impact on various entities' perceptions of an organisation's effectiveness and as such have a very real impact on the continued existence of the organisation. As such, a powerful argument can be put forward that financial data provides a sound basis to make inferences about effectiveness. Financial 
performance data span various dimensions in organisations and logically, therefore, should provide a sound framework to study the link between the culture dimension in an organisation and the system's overall effectiveness.

\section{Financial performance measures}

To determine organisational effectiveness, the following four financial performance measures were applied:

- return on average equity;

- return on average assets;

- total asset growth rate; and

- share return.

The source of financial data on organisations was the $\mathrm{Bu}$ reau for Financial Analysis at the University of Pretoria. To retrieve the required information from the Bureau's data base, the parameters as outlined in Table 2 were applied.

\section{Organisations identified}

Based on the retrieval parameters above, it was found that 166 industrial companies have been listed on the Johannesburg Stock Exchange from 1984 to 1993. Thirty-one of these organisations were industrial holding companies and they were, therefore, eliminated. Of the remaining 135 companies seven were operating outside the borders of South Africa. They were also eliminated. The final number of organisations that would constitute the population for the purpose of this study, therefore, was 128 .

\section{Measurement of financial performance}

In respect of two of the four performance measures, that is total asset growth and share return, a single value for each was computed for the period 1984 to 1993 . In respect of the other two performance measures, that is return on average equity and return on average assets, ten annual values for each were computed. In certain cases the annual value displayed considerable variation and to deal with outlying values only those that fell within plus and minus three standard deviations of the average were included in the calculation of a return on average equity and a return on average assets.

The four financial performance measurements were factor analysed. A principal factor analysis yielded a factor pattern as detailed in Table 3. Only one factor with an eigen value $>1$ emerged from the data. The factor loadings in $\mathrm{Ta}$ ble 3 were then applied to each of the performance measures to arrive at a single performance measurement per organisation.

To test the composite performance measurement, it was compared with opinions expressed by experts operating in the area of investment. A number of pension fund investment managers and stockbrokers were requested to evalu-

$\begin{aligned} & \text { Table } 2 \text { Parameters applied in retrieving financial } \\
& \text { data }\end{aligned}$
\begin{tabular}{ll} 
Type of organisation & $\begin{array}{l}\text { All industrial organisations listed on the } \\
\text { Johannesburg Stock Exchange }\end{array}$ \\
$\begin{array}{l}\text { Time frame } \\
\begin{array}{l}\text { Sector in which the } \\
\text { organisation operates }\end{array}\end{array}$ & All sectors \\
\hline
\end{tabular}

\begin{tabular}{|c|c|}
\hline Variable & Factor 1 \\
\hline 2 & 0.83242 \\
\hline 1 & 0.83068 \\
\hline 4 & 0.48355 \\
\hline 3 & 0.28879 \\
\hline
\end{tabular}

ate each of the 128 companies. Twelve such experts were willing to participate in the study. Kendall's coefficient of concordance was computed to determine the degree of agreement among the twelve experts. The coefficient obtained, $\mathrm{W}=0.7644(\mathrm{p}<0.01)$ indicated a high degree of agreement. Finally, the twelve scores were averaged and correlated with the composite performance measurement as described above. A product-moment coefficient of $r=$ 0.9561 ( $\mathrm{p}<0.001$ ) was obtained.

The conclusion to be drawn from a comparison of hard data with expert opinion, therefore, is that not only is there a high degree of agreement among experts but there is also a significant correlation between their collective view of organisational performance and hard financial performance data.

\section{Statistical relationship between organisational culture and financial performance}

To establish what the relationship is between average culture scores and financial performance, the Spearman rankorder correlation coefficient was computed between each organisation's culture scores and the composite financial performance score. Positive relationships were found to exist between financial performance and all culture measurements, all of which proved to be statistically significant. The correlation coefficients observed are summarised in Table 4 .

Table 4 Rank-order correlation coefficients indicating the relationship between culture dimension and financial performance $(\mathrm{N}=49)$

\begin{tabular}{lcc}
\hline Culture dimension & Correlation coefficient & $\mathrm{p}$ \\
\hline Conflict resolution & 0.3344 & $<0.020$ \\
Culture management & 0.2919 & $<0.050$ \\
Customer orientation & 0.4191 & $<0.010$ \\
Disposition towards change & 0.3184 & $<0.050$ \\
Employee participation & 0.3136 & $<0.050$ \\
Goal clarity & 0.3172 & $<0.050$ \\
Human resource orientation & 0.3453 & $<0.020$ \\
Identification with organisation & 0.2986 & $<0.050$ \\
Locus of authority & 0.3469 & $<0.020$ \\
Management style & 0.3429 & $<0.020$ \\
Organisation focus & 0.3074 & $<0.050$ \\
Organisation integration & 0.3530 & $<0.020$ \\
Performance onientation & 0.2999 & $<0.050$ \\
Reward orientation & 0.3331 & $<0.050$ \\
Task structure & 0.3515 & $<0.020$ \\
\hline
\end{tabular}


The variation in average culture score per organisation was arrived at by computing the coefficient of variation. To establish the relationship between the variation in average culture score and financial performance, the Spearman rank-order correlation coefficient was computed. Negative relationships were found to exist between the variation in average culture scores and financial performance. In all instances the relationship proved to be statistically significant. The correlation coefficients observed are summarised in Table 5 .

By computing the average culture score of each of the 15 dimensions by organisational level, that is management, supervisory and other in each of the companies, it was possible to determine whether statistically significant differences existed between the three organisational levels. By means of the Kruskal-Wallis one-way analysis of variance by ranks test, it was possible to classify companies into one of two categories, namely those in which statistically significant differences between organisational levels existed and those in which no such differences existed. Having classified companies into these categories. it was then possible to establish what the relationship is between the existence or nonexistence of such differences and financial performance by computing the point biserial correlation coefficient. Positive relationships were found to exist in respect of certain culture dimensions all of which proved to be statistically insignificant at the 0.05 level. The correlation coefficients observed are summarised in Table 6 .

In respect of functionally separate units, a measurement was obtained which signified whether a statistically significant difference was observed between average scores of functionally separate units within each organisation in respect of each of the 15 dimensions of organisational culture. To establish what the relationship is between the existence or nonexistence of such differences and financial performance, the point biserial correlation coefficient was

\begin{tabular}{lcc}
\hline $\begin{array}{l}\text { Table } 5 \text { Rank-order correlation coefficients indi- } \\
\text { cating the relationship between culture }\end{array}$ & $\begin{array}{c}\text { dimension } \\
\text { and financial performance }(\mathrm{N}=49)\end{array}$ \\
\hline Culture dinmension & $\begin{array}{c}\text { Correlation } \\
\text { coefficient }\end{array}$ & $\mathrm{p}$ \\
\hline Conflict resolution & -0.3060 & $<0.050$ \\
Culture management & -0.2876 & $<0.050$ \\
Customer orientation & -0.3638 & $<0.020$ \\
Disposition towards change & -0.3143 & $<0.050$ \\
Employee participation & -0.3197 & $<0.050$ \\
Goal clarity & -0.3264 & $<0.050$ \\
Hurnan resource orientation & -0.2869 & $<0.050$ \\
Identification with organisation & -0.3072 & $<0.050$ \\
Locus of authority & -0.3515 & $<0.020$ \\
Management style & -0.3364 & $<0.020$ \\
Organisation focus & -0.3288 & $<0.050$ \\
Organisation integration & -0.3711 & $<0.010$ \\
Performance orientation & -0.3716 & $<0.010$ \\
Reward orientation & -0.3169 & $<0.050$ \\
Task structure & -0.2291 & $<0.050$ \\
\hline
\end{tabular}

Table 6 Point biserial correlation coefficients indicating the relationship between observed differences between organisational levels and financial performance $(\mathrm{N}=49)$

\begin{tabular}{lcc}
\hline Culture dimension & $r_{p}$ m & $p$ \\
\hline Conflict resolution & 0.2583 & $<0.100$ \\
Culture management & 0.1030 & $>0.100$ \\
Customer orientation & 0.0531 & $>0.100$ \\
Disposition towards change & 0.0286 & $>0.100$ \\
Employee participation & 0.0504 & $>0.100$ \\
Goal clarity & 0.0084 & $>0.100$ \\
Human resource orientation & 0.0770 & $>0.100$ \\
Identification with organisation & 0.0019 & $>0.100$ \\
Locus of authority & 0.1256 & $>0.100$ \\
Management style & 0.0821 & $>0.100$ \\
Organisation focus & 0.1236 & $>0.100$ \\
Organisation integration & 0.2377 & $>0.100$ \\
Performance orientation & 0.0486 & $>0.100$ \\
Reward orientation & 0.0000 & $>0.100$ \\
Task structure & 0.0878 & $>0.100$ \\
\hline
\end{tabular}

computed. Positive relationships were found to exist in respect of some culture dimensions all of which proved to be statistically insignificant at the 0.05 level.

In respect of geographically separate units, a measurement was obtained which signified whether a statistically significant difference was observed between average scores of functionally separate units within each organisation in respect of each of the 15 dimensions of organisational culture. To establish what the relationship is between the existence or nonexistence of such differences and financial performance, the point biserial correlation coefficient was

Table 7 Point biserial correlation coefficients indicating the relationship between observed differences between geographically separate units and financial performance $(\mathrm{N}=13)$

\begin{tabular}{lll}
\hline Culture dimension & $r_{p} N$ & $p$ \\
\hline Conflict resolution & 0.2197 & $<0.100$ \\
Culture managentent & 0.0305 & $>0.100$ \\
Customer orientation & 0.1198 & $>0.100$ \\
Disposition towards change & 0.2052 & $>0.100$ \\
Employet participation & 0.1153 & $>0.100$ \\
Goal clarity & 0.3277 & $>0.100$ \\
Human resource orientation & 0.1153 & $>0.100$ \\
Identification with organisation & 0.0000 & $>0.100$ \\
Locus of authority & 0.0309 & $>0.100$ \\
Management style & 0.0000 & $>0.100$ \\
Organisation focus & 0.0000 & $>0.100$ \\
Organisation integration & 0.0000 & $>0.100$ \\
Performance orientation & 0.0734 & $>0.100$ \\
Reward orientation & 0.0000 & $>0.100$ \\
Task structure & 0.0000 & $>0.100$ \\
\hline
\end{tabular}


computed. Positive relationships were found to exist in respect of some culture dimensions all of which proved to be statistically insignificant at the 0.05 level. The correlation coefficients observed are summarised in Table 7.

\section{Statistical relationship between the management of organisational culture and financial perform- ance}

A questionnaire probing the elements of a culture management programme was administered to senior managers in participating organisations. The questionnaire was sent to the senior executive requesting his specific response as well as that of one other senior executive and also that of the senior human resource manager in the organisation. Of the 49 organisations that participated in this study. 38 responded. Ten organisations returned two questionnaires and 28 returned three questionnaires. The overall response rate was $77.6 \%$ of the organisations finally included in the study or $29.7 \%$ of all the organisations initially invited to participate in the study. By means of this questionnaire it was possible to arrive at an average score for each organisation in respect of each of the elements of a culture management programme.
Table 8 Rank-order correlation coefficients indicating the relationship between elements of a culture man agement programme and financial performance $(\mathrm{N}=38)$

\begin{tabular}{lcc}
\hline Elements of programme & $\begin{array}{c}\text { Correlation } \\
\text { coefficient }\end{array}$ & $p$ \\
\hline Formulation of a strategic vision & 0.3248 & $<0.050$ \\
Diagnosis of organisational culture and core values & 0.3725 & $<0.050$ \\
Initiation rites & 0.3320 & $<0.050$ \\
Reinforcing rituals & 0.2500 & $<0.200$ \\
Role modelling & 0.2740 & $<0.100$ \\
Communication & 0.3268 & $<0.050$ \\
Termination rites & 0.3114 & $<0.100$ \\
Assessment of progress & 0.1173 & $<0.200$ \\
\hline
\end{tabular}

To establish what the relationship is between financial performance and each of the eight elements of a culture management programme. the Spearman rank-order correlation coefficient was computed. Positive relationships were found to exist between financial performance and the elements of a culture management programme, some of which

Table 9 Culture perceptions in financially more successful and less successful organisations

\begin{tabular}{ll}
\hline Dimensions of culture & Financially more successful organisations \\
\hline Conflict resolution & $\begin{array}{l}\text { Conflict and criticism openly aired and confronted } \\
\text { Deliberate management action to shape organisation's } \\
\text { Culture management }\end{array}$ \\
$\begin{array}{l}\text { Customer orientation } \\
\text { Disposition towards change }\end{array}$ & $\begin{array}{l}\text { Employees are encouraged to be creative and innovative } \\
\text { Employee participation }\end{array}$ \\
& $\begin{array}{l}\text { Employees participate in decision-making process of the } \\
\text { organisation }\end{array}$
\end{tabular}

Financially less successful organisations

Conflict and criticism ignored and smoothed over

No deliberate management action to shape organisation's culture

Views of customers are not taken seriously or acted upon

Employees are not encouraged to be creative and innovative

Goal clarity

Organisation creates and communicates clear objectives and performance expectations

Human resource

orientation

Organisation views and treats members as a valued resource and important contributor to its success

Identification with the organisation

Organisational members are encouraged to identify with the organisation, to extend business friendships away from work and to become emotionally involved in the organisation

Locus of authority Authority and responsibility dispersed throughout the organisation and members are empowered to make appropriated decisions

Management style Senior members provide clear communication, assistance and suppon to those members reporting to them

Organisation focus

Organisation concentrates on those business activities fundamental to the business

Organisation integration

Organisational subunits are actively encouraged to operate in a co-ordinated way, to co-operate and support each other across work group boundaries

Performance orientation Organisation places high emphasis on individual accountability for clearly defined results as well as demanding performance levels

Reward orientation

Organisation rewards members on the basis of performance and positively reinforces behaviour that supports the organisations objectives

Task structure

Organisation members experience a loose, unregulated by ruies and procedures and informal atmosphere allowing them to be creative and innovative in doing their jobs
Employees do not participate in decision-making process of the organisation

Organisation does not create and communicare clear objectives and performance expectations

Organisation does not view or treat members as a valued resource and important contributor to its success

Organisational members are not encouraged to identify with the organisation, to extend business friendships away from work or to become emotionally involved in the organisation

Authority and responsibility located at the top of the organisation and members are not empowered to make appropriated decisions

Senior members do not provide clear communication, assistance and support to those members reporting to them

Organisation does not concentrate on those business activities fundamental to the business and gets involved in peripheral activities

Organisational subunits are not actively encouraged to operate in a co-ordinated way, to co-operate and support each other across work group boundaries

Organisation does not place high emphasis on individual accountability for clearly defined results or demanding performance levels

'r zanisat: . "ewards members on the basis of considerations other than performance and tends to rather punish negatively behaviour that does not suppoit the organisations objectives

Member behaviour is managed by means of rules, regulations, policies and procedures and strict direct supervision 
proved to be statistically significant. The correlation coefficients observed are summarised in Table 8.

\section{Findings and conclusions}

The findings and conclusions arrived at may be summarised as follows.

In the first place, organisations that are financially more effective differ from those that are not, in respect of all the organisation culture dimensions selected for this study. The conclusion that may be drawn from this finding is that organisations are likely to be financially more successful if their members experience the organisational culture dimensions as summarised in Table-9. The ab'

Secondly, organisations that are financially more effective differ from those that are not with regard to the degree to which perceptions of the organisational culture vary between organisational members. The conclusion that may be drawn from this finding is that organisations in which there is a lesser degree of variation in member perception of the extent to which they experience the the cultural dimensions, are likely to be financially more successful than those organisations where there is a greater degree of variation in member perception of the cultural dimensions.

Thirdly, differences in perceptions about organisational culture dimensions between organisation level, functional unit and geographical location do not differentiate between organisations that are financially more effective and those that are not. The conclusion to be drawn therefore, is that those organisations in which there is a greater degree of agreement between member perception at different organisational levels, at different functional units and at different geographical units of the extent to which they experience the cultural dimensions, are not likely to be financially more successful than those organisations where there is a lesser degree of agreement in member perception at different organisational levels, functional and geographical units of the cultural dimensions.

Finally, it was established that not all of the elements of culture management programmes correlate significantly with organisational effectiveness. The conclusions to be drawn from this finding may be summarised as follows:

- organisations that have developed strategic visions that include organisational values that are widely accepted by organisational members, are likely to be financially more successful than those organisations that do not;

- organisations that regularly review their organisational culture and core values against husiness strategy and plans so as to assess the appropriateness of the culture and values in terms of prevailing environmental demands, are likely to be financially more successful than those organisations that do not;

- organisations that have recruitment, orientation and initial training procedures designed to communicate its core values to employees so that they may know what they are expected to adhere to, are likely to be financially more successful than those organisations that do not;

- organisations that design and select rituals in respect of the reward system, performance measurement and assessment programmes, supervisory training and man- agement development to reinforce a specifically desired set of behaviours, are not necessarily likely to be financially more successful than those organisations that do not;

- organisations that identify role models that are publicly held as persons whose behaviour and actions should be emulated, are not necessarily likely to be financially more succe ssful than those organisations that do not;

- organisations that consistently apply communication systems to transmit its core values to all employees, are likely to be financially more successful than those organisations that do not;

- organisations that have systems and procedures regarding the termination of employment that have special meaning and intent for shaping employee behaviour and reinforcing organisational values, are not necessarily likely to be financially more successful than those organisations that do not; and finally,

- organisations that audit or measure their organisational culture with a view towards achieving a specifically desired culture, are not necessarily likely to be financially more successful than those organisations that do not.

The findings should not be interpreted as universal or as a one best form of organisational culture for effectiveness. Longstanding research of repute $h_{\text {.. }} \&$ adequately demonstrated the need for a contingency approach that recognises the fit among task, organisation and people. What is however, suggested by the findings is that the utilisation of human resources and the harnessing of human potential is an important element in the effective and successful management of an enterprise.

\section{References}

Argyris, C. 1964. Integrating the individual and the organisation. New York: John Wiley, $330 \mathrm{p}$.

Ball, A. \& Asbury, S. 1989. The winning wat: Johannesburg: Jonathan Ball, 266p.

Barney, J.B. 1986. Organisational culture: can it be a source of sustained competitive advantage? Accudemy of Management Re. view, 11 (3): 656-665.

Bower, M. 1966. The will to manage. New York: McGraw-Hill. $276 \mathrm{p}$.

Cameron, K.S. \& Whetten, D.A. 1983. Organisation effectiveness. A comparison of multiple models. New York: Academic Press, $291 \mathrm{p}$.

Davis S. 1984. Managing corporale culture. Cambridge, Massachusetts: Balinger. 12.3p.

Deal, T. E. \& Kinnedy. A.A. 1982. Corporale cultures: the rites and rules of corporate life. Reading, Massachusetts: AddisonWesley, 232p

Denison. D.R. 1990. Corporate culture and organisation effectiveness. New York: John Wiley, 267p.

Drennan, D. 1992. Transforming company culture. London: McGraw-Hill, 299p.

Drucker, P.F. 1973. Management. New York: McGraw-Hill, 389p.

French, W.L. \& Bell, C.H. 1984. Organisation development. Englewood Cliffs, New Jersey: Prentice-Hall, 247p.

Green, L. 1989. Corporate culture: asset or liability, Human Resources Management Yearbook: 72-74.

Kilman, R.H., Saxton, M.J. \&Serpa, R. 1980. Issues in understanding and changing culture. California Management Review. Winter: $87-9.3$. 
Kotter, J.P. \& Heskett, J.L. 1992. Corporate Culture and Performance. New York: The Free Press, 214p.

Likert, R. 1961. New patterns of management. New York: McGraw-Hill, 279p.

McGregor, D. 1960. The human side of enterprise. New York: McGraw-Hill, 246p.

McIntyre Ray, B.G. The relationship of job satisfaction, individual characteristics and leadership style to corporate culture beliefs and climate for change. Unpublished D Ed dissertation. Graduate School of East Texas State University, 200p.

Nasser, M.E. \& Vivier, F.J. 1993. Mindset for the new generation organisation. Kenwyn: Juta, 169p.

Ott, J.S. 1989. The organisation culture perspective. Pacific Grove: Brooks-Cole, 231p.

Ouchi, W.G. 1981. Theory Z. Reading Massachusetts: AddisonWesley, 244p.

Pascale, R.T. \& Athos, A.G. 1981. The art of Japanese management. New York: Simon and Schuster, 221p.

Peters, T.J. \& Waterman, R.H. 1982. In search of excellence. Lessons from America's best run companies. New York: Harper and Row, 360p.

Porter, L.W., Lawler, E.E. \& Hackman, J.R. 1975. Behaviour in organisations. New York: McGraw-Hill, 561p.
Quinn, R.E. 1988. Beyond rational management. San Francisco: Jossey-Bass, 199p.

Robbins, S.P. 1990. Organisation theory. Structure design and ap. plications. New Jersey: Prentice Hall, 552p.

Roethlisberger, F.J. \& Dickson. W.J. 1975. Management and the worker. An account of a research programme conducted by Western Electric Company, Hawthorne Works Chicago. Cambridge: Harvard University Press, 613p.

Schein, E.H. 1990. Organisation culture, American Psychologist, 45(2): 109-1 19.

Schein, E.H. 1992. Organisational culture and leadership. San Francisco: Jossey-Bass, 418p.

Schuster, F.E. 1986. The Schuster Report. The proven connection between people and profits. New York: John Wiley, 200p.

Smircich, L. 1983. Concepts of culture and organisation analysis, Administrative Science Quarterly, September: 339-358.

Tosi, H.L., Rizzo, J.R. \& Carrol, S.J. 1990. Managing organisational behaviour. New York: Harper Collins, 805p.

Williams, A., Dobson, P. \& Walters, M. 1990. Changing culture. London: Institute of Personnel Management, 230p.

White, J. 1991. Corporate culture and corporate success, South African Handbook of Management Development, 6(6): 17-22. 